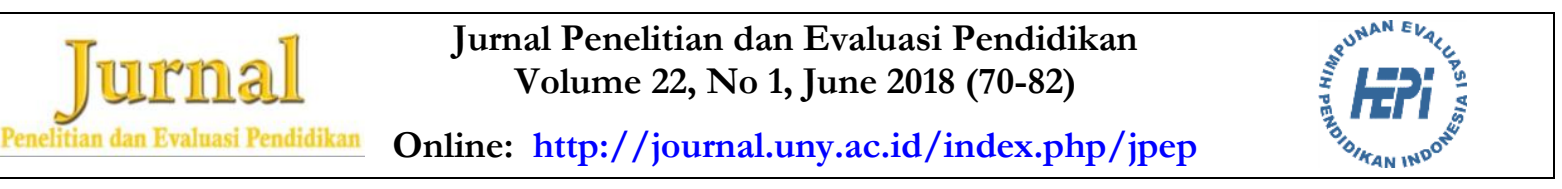

\title{
MODEL EVALUASI IMPLEMENTASI KEBIJAKAN STANDAR PELAYANAN MINIMAL PADA SATUAN PENDIDIKAN JENJANG SD
}

\author{
Lilik Sabdaningtyas \\ FKIP-Universitas Lampung \\ Jl. Prof. Sumantri Brojonegoro No.1, Rajabasa, Gedong Meneng, Rajabasa, Kota Bandar \\ Lampung, Lampung 35145, Indonesia \\ Email: lilik_sabdaningtyas@yahoo.co.id
}

\begin{abstract}
Abstrak
Tujuan penelitian ini untuk menghasilkan model evaluasi implementasi kebijakan standar pelayanan minimal (SPM) jenjang sekolah dasar (SD). Hasil evaluasi diharapkan dapat memberikan rekomendasi kepada Dinas pendidikan dan para praktisi pendidikan. Desain penelitian yang digunakan adalah non experimental. Desain penelitian ini terdiri dari 5 variabel laten dan 33 variabel manifest. Populasinya mencakup 307 SD di 11 Kecamatan wilayah Kabupaten Pesawaran. Sampel sebanyak 24 SD pada 4 Kecamatan diambil secara purposive. Instrumen pengumpulan data yang digunakan adalah kuesioner yang divalidasi dan conten validity melalui Focus Group Discucion (FGD). Data yang terkumpul dianalisis menggunakan Structural Equation Models (SEM). Hasil penelitian menunjukkan bahwa Kondisi Lingkungan Sekolah (KLS), Pelaksana Kebijakan Sekolah (PKS), Kelompok Sasaran Kebijakan (KSK), dan Proses Pengelolaan Organisasi Sekolah (PPOS) merupakan faktor dinamis pembentuk model yang tepat untuk mengevaluasi IP-SPM SD.
\end{abstract}

Kata kunci: model evaluasi, implementasi kebijakan, IP-SPM-SD

\section{EVALUATION MODEL OF MINIMUM SERVICE STANDARD POLICY IMPLEMENTATION AT ELEMENTARY EDUCATION LEVEL}

\begin{abstract}
The purpose of this research is to produce evaluation model of minimum service standard implementation at elementary education level. The evaluation results are expected to provide recommendations to education authorities and practitioners. The research employed non experimental design. This research design consisted of five latent variables and 33 manifest variables. Its population includes 307 elementary schools in 11 sub-districts of Pesawaran Regency. Purposive sampling technique was used to select 24 elementary schools in four subdistricts. The data collection instrument used in this study was questionnaire which was validated by content validity through focus group discussion (FGD). The collected data were analyzed using structural equation model (SEM). The results of the research show that the condition of school environment, school policy executors, policy-target group, and school organizational management process are the appropriate dynamic modeling factor to evaluate the achievement index of minimum service standard at elementary education level. Hasil penelitian menunjukkan bahwa Kondisi Lingkungan Sekolah (KLS), Pelaksana Kebijakan Sekolah (PKS), Kelompok Sasaran Kebijakan (KSK), dan Proses Pengelolaan Organisasi Sekolah (PPOS) merupakan faktor dinamis pembentuk model yang tepat untuk mengevaluasi IP-SPM SD
\end{abstract}

Keywords: evaluation model, policy implementation, IP-SPM-S

Permalink/DOI: bttp:/ / dx.doi.org/10.21831/pep.v22i1.19638

Jurnal Penelitian dan Evaluasi Pendidikan

ISSN 1410-4725 (print) ISSN 2338-6061 (online) 


\section{Pendahuluan}

Reformasi dalam penyelenggaraan pemerintahan di Indonesia telah menyebabkan terjadinya sejumlah perubahan penting dan mendasar dalam tata kelola pemerintahan yang pada akhirnya berimplikasi pada penyelenggaraan pelayanan publik di daerah. Lembaga pendidikan yang merupakan lembaga pelayanan publik juga mengalami perubahan.

Terkait dengan penyelenggaraan pelayanan publik di bidang pendidikan, pemerintah telah memformulasikan Peraturan Menteri Pendidikan dan Kebudayaan (Permendikbud) No 23 Tahun 2013 tentang Standar Pelayanan Minimal (SPM) Pendidikan Dasar di Kabupaten/Kota. Permendikbud tersebut telah diformulasikan sejak tahun 2011 dan ditargetkan tahun 2014 seluruh pelayanan minimal pendidikan Dasar di seluruh Kabupaten/Kota telah terpenuhi (Menteri Pendidikan dan Kebudayaan Republik Indonesia, 2013).

Hingga saat ini yakni tahun 2018 implementasi kebijakan tersebut telah berjalan selama kurun waktu tujuh tahun. Untuk mengetahui efektivitas implementasinya maka perlu dilakukan evaluasi, dengan harapan hasil evaluasi bisa dijadikan pemetaan dalam rangka Pemerintah Daerah mendistribusikan bantuan kepada sekolah-sekolah.

Mengacu pada Permendikbud No 23 Tahun 2013, SPM pendidikan dasar adalah merupakan tolok ukur kinerja pelayanan pendidikan dasar melalui jalur pendidikan formal yang diselenggarakan oleh Pemerintah Kabupaten/Kota. SPM pendidikan merupakan ketentuan tentang jumlah dan mutu layanan pendidikan yang diselenggarakan oleh Pemerintah Kabupaten/Kota, Kantor Wilayah Kementerian Agama, dan Kantor Kementerian Agama Kabupaten/Kota secara langsung maupun secara tidak langsung melalui sekolah dan madrasah. Tujuan penerapan SPM dimaksudkan untuk memastikan bahwa di setiap sekolah dan madrasah terpenuhi kondisi minimum yang dibutuhkan untuk menjamin terselenggaranya proses pembelajaran yang memadai. SPM diharapkan mampu mempersempit kesenjangan mutu pendidikan yang kedepannya juga diharapkan berimplikasi pada mengecilnya kesenjangan sosial ekonomi.

Menyikapi tentang implementasi kebijakan pemerintah yang tertuang dalam Permendikbud No 23 Tahun 2013 tentang SPM Pendidikan Dasar di Kabupaten/Kota. Pemerintah telah melakukan berbagai upaya agar target bisa tercapai. Beberapa upaya tersebut diantaranya adalah rehabilitasi sarana dan prasarana pada satuan sekolah, pelatihan guru, sertifikasi guru dan lain-lain. Namun kenyataan di lapangan ternyata belum menggembirakan, hal ini terlihat masih adanya beberapa permasalahan sehubungan dengan implementasi kebijakan SPM.

Beberapa permasalahan tersebut diantaranya adalah; (1) implementasi kebijakan tersebut telah memasuki tahun ke tujuh dan telah melebihi target yang ditetapkan Pemerintah yakni tahun 2014 SPM harus tercapai. Ini bisa dimaknakan bahwa target pencapaiannya tidak terpenuhi, seharusnya pada tahun 2014 semua jenjang SD telah memenuhi standar pelayanan dasar; (2) pelaksanaan SPM tentu tidaklah semudah membalikkan tangan. Hal ini mengingat bahwa tidak menjadi jaminan bagi setiap daerah dan satuan pendidikan mampu memberikan pelayanan yang berkualitas kepada masyarakat dalam waktu yang relatif singkat yang sesuai target pemerintah yakni 3 tahun berjalan; (3) disisi lain kesiapan daerah maupun satuan sekolah untuk melaksanakan tugas pelayanan ini relatif terbatas baik dari segi sumber daya, kelembagaan, maupun keuangannya; (4) permasalahan lain adalah disparitas kapasitas daerah maupun sekolah dalam melaksanakan pelayanan dasar di era otonomi daerah menunjukkan tingkat kesenjangan yang cukup tinggi, namun daerah dan satuan sekolah harus tetap melaksanakan SPM yang sama secara nasional; (5) fakta lain, sebagaimana hasil penelitian yang dilakukan oleh Adawiah (2011) menunjukkan bahwa SPM pendidikan dasar di Kabupaten Balangan umumnya masih jauh dari harapan. Solongi (2015) yang mengacu pada data hasil pemetaan Kemendikbud menunjukkan bahwa dari $148.061 \mathrm{SD} / \mathrm{MI} / \mathrm{SMP} / \mathrm{MTS}$ yang tersebar di seluruh tanah air yang dihuni 
sebanyak 26.119.000 murid, masih ada 75\% yang tidak memenuhi SPM. Terdapat puluhan ribu sekolah yang masih dalam kondisi rusak. Jumlah ruang kelas SD dan SMP yang rusak berat diperkirakan mencapai 739,741. Kondisi ini mengindikasikan bahwa SPM belum sepenuhnya terimplementasi di seluruh daerah. Hasil penelitian Hermawan (2011, pp. 619-634), menunjukkan bahwa hanya 23 sekolah $(52,27 \%)$ yang telah mencapai standar nasional pendidikan (SNP), sedangkan 21 sekolah $(47,73 \%)$ lainnya belum mencapai. Berdasarkan fakta empirik ini, perlu dilakukan evaluasi untuk mengetahui faktor-faktor apa yang menjadi penyebab sehingga target SPM belum terpenuhi.

Permasalahan tersebut sangat menarik perhatian untuk diteliti mengingat: (1) kebijakan tentang implementasi SPM khususnya pada satuan sekolah jenjang SD merupakan masalah yang aktual, (2) kebijakan dan program yang tidak dievaluasi implementasinya maka tidak akan diketahui kelemahan dan kelebihannya dalam rangka pengembangan, kelanjutan, atau pemberhentian program tersebut.

Berdasarkan permasalahan dan argumen tersebut perlu dikembangkan sebuah model evaluasi yang tepat yakni; "Model Evaluasi Implementasi Kebijakan SPM pada Satuan Pendidikan Jenjang SD di Kabupaten Pesawaran".

Menurut Dunn (1998, pp. 608-610) secara umum istilah evaluasi dapat disamakan dengan penaksiran (appraisa), pemberian angka (rating) dan penilaian (assesment) sebagai usaha untuk menganalisis hasil kebijakan. Rossi \& Freeman (1982, p. 4) mengklasifikasikan tiga besar evaluasi kebijakan yaitu: (a) evaluasi pada tahap rancangan dan konseptualisasi program; (b) evaluasi pada tahap implementasi program (monitoring dan akuntabilitas); (c) evaluasi pada tahap kegunaan program (pengukuran efisiensi dan impact). Kemudian berdasar fungsinya, evaluasi kebijakan dibedakan menjadi empat. Pertama, Eksplanasi. Dalam eksplanasi dapat dibuat suatu gambaran tentang pola-pola hubungan antarberbagai demensi realita yang dapat diamatinya. Melalui Eksplanasi dapat diketahui variabel-variabel kebijakan yang mempengaruhi keberhasilan suatu kebijakan. Dengan demikian dapat diidentifikasi tentang tujuan-tujuan dari program utama yang potensial untuk tercapai, mengapa tujuan itu harus dicapai dan bagaimana mencapainya. Kedua, Kepatuhan. Kepatuhan berfungsi untuk melihat apakah tindakan yang dilakukan oleh pelaku (birokrasi maupun pelaku lain) sesuai dengan standar dan prosedur yang ditetap-kan oleh kebijakan. Ketiga, Fungsi auditing. Ini berfungsi untuk melihat apakah output benar-benar sampai ke tangan kelompok sasaran maupun penerima lain (individu, organisasi, dll) yang dimaksud oleh pembuat kebijakan. Keempat, Akunting. Fungsi ini adalah untuk melihat apakah akibat sosial ekonomi dari kebijakan tersebut. Lebih lanjut dikemukakan bahwa tujuan evaluasi kebijakan pada dasarnya adalah: (1) untuk me-ngetahui proses pembuatan kebijakan, (2) untuk mengetahui proses implementasi, (3) untuk mengetahui konsekuensi kebijakan, dan (4) untuk mengetahui efektivitas dampak kebijakan (Wibawa, Prabuningrat, \& Pramusinto, 1994, pp. 910).

Untuk melakukan evaluasi diperlukan model evaluasi tertentu. Worthen \& Sanders (1973, p. 20) mengemukakan evaluasi program adalah suatu proses mengidentifikasi dan mengumpulkan informasi untuk membantu para pengambil keputusan dalam memilih berbagai alternatif keputusan. Sudjana (2006, p. 51) mengemukakan, model evaluasi program mencakup lebih dari 50 jenis yang telah dan sedang digunakan dalam evaluasi program. Model-model tersebut dapat dikelompokkan ke dalam enam kategori yaitu: (1) model evaluasi terfokus pada pengambilan keputusan; (2) model evaluasi terhadap unsur-unsur program; (3) model evaluasi terhadap jenis/tipe kegiatan program; (4) model evaluasi terhadap proses pelaksanaan program; (5) model evaluasi terhadap pencapaian tujuan program; dan (6) model evaluasi terhadap hasil dan pengaruh program. Berdasarkan telaah tentang evaluasi kebijakan (policy evaluation) di atas, maka harus difahami bahwa untuk me- 
lakukan evaluasi kebijakan kita harus melakukan pilihan-pilihan terhadap beberapa hal agar pelaksanaan evaluasi terfokus dan sesuai dengan fenomena yang akan kita evaluasi. Pilihan-pilihan yang dimaksud adalah pilihan evaluasi menurut tahapannya, menurut bentuk, menurut fungsi, menurut tujuannya, menurut model, dan menurut scope-nya.

Istilah kebijakan secara sederhana dapat diartikan sebagai "pedoman untuk bertindak". Kebijakan dalam maknanya seperti ini bisa berupa suatu deklarasi mengenai suatu dasar pedoman bertindak, suatu arah tindakan tertentu, suatu program mengenai aktivitas-aktivitas tertentu atau suatu rencana. Dengan kata lain kebijakan juga dapat merupakan ketentuan-ketentuan yang harus dijadikan acuan, pedoman, pegangan, dan petunjuk serta cara bagi setiap usaha dan kegiatan sehingga tercapai kelancaran dan keterpaduan dalam mencapai tujuan tertentu. Implementasi kebijakan merupakan salah satu tahapan dalam keseluruhan proses kebijakan yaitu tahap formulasi, tahap implementasi, dan tahap evaluasi yang berlangsung dalam suatu sistem kebijakan yang komplek dan dinamik serta akan menentukan berhasil atau gagalnya suatu kebijakan. Oleh karena itu implementasi kebijakan adalah merupakan suatu tahapan penting dalam proses kebijakan untuk dikaji agar bisa mengantisipasi terhadap keberhasilan kebijakan itu sendiri. Definisi sederhana dari istilah implementasi adalah "penerapan atau pelaksanaan". Implementasi kebijakan bersifat interaktif dengan kegiatan kebijakan yang mendahuluinya yakni formulasi kebijakan. Oleh karena itu implementasi kebijakan dapat dipandang sebagai sebuah proses interaksi antara suatu perangkat tujuan dan tindakan yang harus dilakukan.

Ada tiga kegiatan penting yang berkaitan dengan tahapan implementasi kebijakan yaitu; organisasi, interpretasi, dan penerapan. Dalam hal ini organisasi adalah memerlukan perhatian yang paling utama karena sangat penting bagi pembahasan konsep birokrasi serta bentuk-bentuknya yang terkait sekali dengan sebuah kebijakan (Jones, 1994, pp. 294-296). Organisasi yang dimaksudkan oleh Jones adalah pembentukan atau penataan kembali sumber daya, unit-unit serta metode untuk menjadikan program berjalan. Dalam pelaksanaan sebuah kebijakan tentu diperlukan adanya organisasi agar pekerjaan dapat dilaksanakan.

Selain hal tersebut bahwa implementasi sebuah kebijakan akan sangat dipengaruhi berbagai faktor. Faktor-faktor yang berpengaruh terhadap implementasi kebijakan yang dikemukakan beberapa ahli diantaranya; Grindle (1980), Mazmanian \& Sabatier (1986), Edwards III (1980), Van Meter \& Van Horn (1973), Cheema \& Rondinelli (1983), dan Koster (2000). Menurut peneliti, beberapa faktor yang mempengaruhi implementasi kebijakan sebagaimana pendapat para ahli di atas, jika dikelompokkan terdapat kesamaan 4 (empat) aspek utama sebagai faktor pendukung implementasi kebijakan yaitu: (a) aspek yang terkait dengan kondisi lingkungan; (b) aspek yang terkait dengan isi kebijakan; (c) aspek yang terkait dengan karakteristik organisasi pelaksana; (d) aspek yang terkait dengan karakteristik kelompok sasaran (target group). Disamping empat aspek tersebut, terdapat satu aspek penting lain yang merupakan pendukung implementasi kebijakan yakni proses pengelolaan organisasi (Sabdaningtyas, 2010). Dengan mengacu pada beberapa pendapat tersebut di atas, bahwa kondisi lingkungan, pelaksana kebijakan, kelompok sasaran kebijakan, dan proses pengelolaan organisasi merupakan faktor-faktor pendukung implementasi kebijakan SPM pada satuan pendidikan jenjang SD.

\section{Indikator Model Evaluasi Implementasi Kebijakan SPM SD}

Indikator adalah karakteristik yang dapat diobservasi secara langsung sebagai ganti dari karakteristik yang tak dapat diamati secara langsung dan digunakan sebagai definisi operasional atas suatu variabel (Dunn, 1998, p. 597). Secara sistemik, model evaluasi implementasi kebijakan bukan merupakan fenomena yang berdiri sendiri melainkan merupakan hasil transformasi berbagai inputs melalui suatu komponen throughput 
(proses) tertentu, maka evaluasi implementasi kebijakan juga dapat menyentuh berbagai indikator baik pada komponen input maupun komponen throughput, dan dipengaruhi pula oleh maksud dan tujuan evaluasi itu dilakukan yakni bertujuan untuk pemantauan, pengawasan atau pertanggung jawaban. Dalam penelitian ini akan dilakukan evaluasi implementasi kebijakan SPM pada satuan pendidikan jenjang SD yang termasuk kegiatan yang bertujuan untuk pemantauan.

Mustopadidjaja (2002, p. 45) menguraikan evaluasi implementasi kebijakan yang dilakukan dengan tujuan pemantauan dimaksudkan untuk mendapatkan informasi dini mengenai perkembangan pelaksanaan pada momentum atau dalam jangka waktu tertentu sehingga dapat diketahui hal-hal yang perlu diperbaiki mengenai sistem dan proses pelaksanaan kebijakan tersebut agar pelaksanaan kebijakan dapat berjalan optimal. Disamping memuat tentang gambaran perkembangan pelaksanaan, dalam evaluasi pemantauan juga memuat identifikasi kelemahan-kelemahan, penyimpangan yang terjadi serta potensi atau daya dukung yang ada selama proses pelaksanaan kebijakan tersebut. Berdasarkan telaah beberapa teori para ahli evaluasi implementasi kebijakan, maka indikator yang digunakan untuk mengukur tiap-tiap variabel dalam penelitian ini menggunakan pola fikir sistemik yakni dengan mengangkat beberapa komponen yang meliputi Policy input, Policy cycle, dan Policy output. peneliti menyingkat dan menamakan model ini sebagai model IPO (Input, Proses, dan Output). Komponen IPO dalam penelitian ini diuraikan sebagai berikut.

Pertama, komponen Policy Output (keluaran kebijakan) adalah barang, jasa atau sumber daya yang diterima oleh kelompok sasaran dan pihak yang menerima akibat (Dunn, 1998, p. 597). Variabel dalam komponen policy output dalam penelitian ini adalah IP (Indek Pencapaian) SPM SD. Indikator yang digunakan untuk mengevaluasi komponen ini mengacu pada Lampiran II Permendikbud No 23 tahun 2013 tentang SPM Pendidikan Dasar di Kabupaten/ Kota.
Kedua, komponen Policy Cycle (Proses). Proses merupakan rangkaian kegiatan yang meliputi tiga kelompok kegiatan utama yaitu formulasi kebijakan, implementasi kebijakan, dan evaluasi kinerja kebijakan (Mustopadidjaja, 2002, p. 3). Policy cycle dalam penelitian ini hanya difokuskan pada tahap implementasi kebijakan. Dalam bukunya, Dunn (1998, p. 598) mengartikan implementasi sebagai kegiatan dan sikap administratif, organisasional yang menentukan transformasi masukan kebijakan menjadi keluaran. Dalam penelitian ini implementasi diartikan sebagai suatu proses pengelolaan input sehingga variabel yang dipilih dalam komponen policy cycle adalah variabel proses pengelolaan organisasi sekolah (PPOS). Variabel PPOS yang dimaksud adalah proses pengelolaan organisasi sekolah oleh birokrat sekolah dalam rangka melaksanakan IP-SPM SD. Komponen proses ini pada dasarnya mempertanyakan apakah proses pengelolaan organisasi sekolah telah dilaksanakan sesuai dengan ketentuan yang berlaku. Proses pengelolaan organisasi sekolah efektif bila mempertimbangkan tiga komponen yakni: (1) struktur organisasi jelas, (2) pola hubungan yang dijalin dalam organisasi tersebut baik, dan (3) ketepatan jenis organisasi yang diterapkan. Pola hubungan yang dijalin dalam organisasi sekolah tidak lagi bersifat hierarki tetapi lebih bersifat fungsional, konsultatif, kemitraan dan koordinatif, dengan demikian perlu dikembangkan jenis organisasi yang non struktural, fungsional dan organik semacam corporate organization (Satori, 1999, p. 17). Berdasarkan uraian di atas, maka indikator yang digunakan dalam variabel PPOS adalah: (1) Struktur organisasi yang meliputi kompleksitas, formalitas, dan sentralisasi; (2) Pola hubungan yang diciptakan dalam organisasi sekolah hendaknya fungsional, konsultatif, kemitraan, dan koordinatif jadi bukan lagi pola hubungan yang otoriter; (3) Jenis organisasi yang digunakan hendaknya organisasi yang demokratis atau non struktural dan fungsional yang didasarkan atas profesi keahliannya.

Ketiga, Komponen Policy Input. Policy input adalah beberapa faktor dinamik yang 
saling berinteraksi dan harus tersedia karena dibutuhkan untuk berlangsungnya proses kebijakan (Mustopadidjaja, 2002, p. 3). Faktor-faktor dinamik yang harus tersedia sebagai komponen policy input dalam penelitian ini meliputi: variabel kondisi lingkungan, variabel pelaksana, dan variabel kelompok sasaran. Komponen policy input ini pada dasarnya adalah mempertanyakan apakah lingkungan kebijakan, pelaksana, dan kelompok sasaran sebagai input kebijakan mendukung terhadap kinerja implementasi kebijakan SPM pada satuan pendidikan. Masing-masing variabel dalam komponen policy input ini akan diukur dengan beberapa indikator yang diuraikan sebagai berikut.

Pertama, variabel Kondisi Lingkungan Sekolah (KLS). Variabel kondisi lingkungan sekolah diukur dengan tiga indikator yakni: (a) Kondisi geografis, ini akan dilihat letak/keberadaan satuan sekolah secara geografis; (b) Kondisi sosial dan kondisi ekonomi, ini akan dilihat dari kondisi rata-rata tingkat pendidikan dan kondisi rata-rata tingkat ekonomi masyarakat/orang tua siswa pada satuan sekolah; (c) Kondisi politik, ini akan dilihat besar kecilnya dukungan para elit politik dalam ikut serta mewujudkan terlaksananya SPM sekolah.

Kedua, variabel Pelaksana Kebijakan Sekolah (PKS). Variabel pelaksana kebijakan sekolah mengukur variabel tersebut adalah: (a) Aspek communication. Dengan indikator bahwa antar pelaksana kebijakan pada satuan pendidikan tidak terjadi perbedaan pandangan terhadap kebijakan program SPM pendidikan pada satuan sekolah yang akan dilaksanakan, yang disebabkan karena komunikasi antar pelaksana kebijakan lancar dan mudah dimengerti semua pihak; (b) Aspek resources. Dengan indikator ketaatan/ kepatuhan personil-personil pelaksana dalam menjalankan tugasnya sesuai dengan kedudukan, tugas dan fungsinya sebagai pelaksana program; (c) Aspek sikap pelaksana. Dengan indikator para pelaksana bersikap positif terhadap kebijakan yang akan dilaksanakan, ini ditunjukkan dengan adanya para pelaksana di tingkat satuan sekolah mempu- nyai persepsi yang baik dan sama terhadap implementasi kebijakan SPM sekolah.

Ketiga, variabel Kelompok Sasaran Kebijakan (KSK) Kelompok sasaran kebijakan adalah orang atau sekelompok orang atau organisasi-organisasi dalam masyarakat yang perilaku dan atau keadaannya akan dipengaruhi oleh kebijakan (Mustopadidjaja, 2002 , p. 8). Variabel ini diukur melalui tiga indikator yaitu: (a) Aspek targetgroup menerima kebijakan yang diimplementasikan, yang indikatornya adalah mereka merasa membutuhkan dan juga memperoleh manfaat dari kebijakan yang diimplementasikan; (b) Aspek targetgroup bersikap netral/acuh tak acuh, dengan indikator mereka tidak menyadari manfaat dari kebijakan SPM. c) Aspek targetgroup menolak kebijakan yang diimplementasikan, dengan indikator sematamata karena mereka tidak menyukai perubahan karena sama sekali tidak memperoleh manfaat dari kebijakan yang diimplementasikan.

\section{Kerangka Pikir Penelitian}

Sebuah kebijakan akan menjadi impian yang tersimpan sebagai arsip belaka bila tidak diimplementasikan dengan efektif. Implementasi kebijakan merupakan aspek penting yang bisa menentukan berhasil atau gagalnya suatu kebijakan. Kebijakan tentang SPM SD telah diformulasikan sejak tahun 2011 dan hingga saat ini implementasinya telah berjalan selama kurun waktu lima (5) tahun. Untuk mengetahui efektivitas implementasi kebijakan SPM pada satuan pendidikan yang saat ini sedang berlangsung maka perlu dilakukan evaluasi. Untuk keperluan evaluasi diperlukan model evaluasi yang tepat agar hasil evaluasi menjadi akurat. Oleh karena itu perlu dikembangkan model evaluasi yang tepat untuk mengukur Indek Pencapaian (IP) implementasi kebijakan SPM pada satuan pendidikan jenjang SD. 


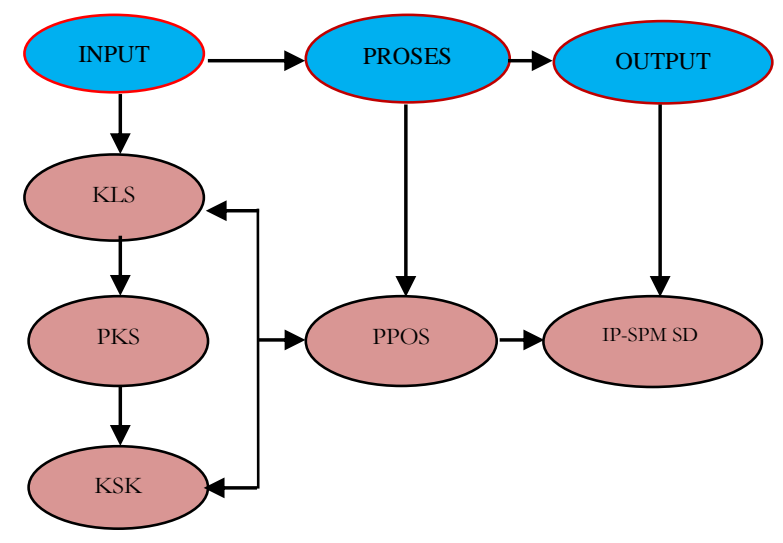

Gambar 1. Kerangka Pikir Penelitian

Pengembangan model implementasi kebijakan SPM SD yang dimaksud adalah membuat model yang didasarkan atas pengkajian terhadap kerangka teoritis yang kemudian diuji berdasarkan fakta empiris. Dalam konsep teoritis, untuk mencapai tujuan kebijakan (policy output) harus dilakukan aksi atau tindakan yang berupa penghimpunan sumber daya yang disebut input kebijakan (policy input) dan pengelolaan sumber daya yang disebut siklus kebijakan (policy cycle/ Proses) yang merupakan tahapan formulasi, implementasi, dan evaluasi kebijakan. Penelitian ini hanya memfokuskan pada tahapan implementasi kebijakan (policy implementation). Selanjutnya bahwa untuk menghasilkan implementasi kebijakan yang efektif maka diperlukan faktor-faktor dinamik yang terdiri dari: kondisi lingkungan kebijakan, pelaksana kebijakan, kelompok sasaran kebijakan, yang ketiganya merupakan input kebijakan dan akan berperan dalam penyelenggaraan siklus/proses kebijakan (policy cycle). Berdasarkan konsep teoritis tersebut, maka kerangka pikir penelitian ini dapat dilihat dalam bagan sebagaimana Gambar 1.

\section{Hipotesis Penelitian}

Beberapa hipotesis penelitian diuraikan sebagai berikut. Pertama, kondisi lingkungan sekolah, pelaksana kebijakan sekolah, kelompok sasaran kebijakan, dan proses pengelolaan organisasi sekolah merupakan faktor-faktor dinamis yang membentuk model yang tepat untuk mengevaluasi indek pencapaian standar pelayanan minimal (IPSPM) satuan pendidikan jenjang SD
Kedua, proses pengelolaan organisasi sekolah merupakan pendukung langsung yang signifikan terhadap indek pencapaian standar pelayanan minimal pada satuan pendidikan jenjang SD. Ketiga, proses pengelolaan organisasi sekolah didukung langsung secara signifikan oleh kondisi lingkungan sekolah, pelaksana kebijakan sekolah, dan kelompok sasaran kebijakan sekolah.

Keempat, indek pencapaian standar pelayanan minimal pada satuan pendidikan jenjang SD didukung langsung secara signifikan oleh kondisi lingkungan sekolah, pelaksana kebijakan, kelompok sasaran kebijakan, dan proses pengelolaan organisasi sekolah. Kelima, kondisi lingkungan sekolah, pelaksana kebijakan, dan kelompok sasaran kebijakan merupakan pendukung tidak langsung secara signifikan terhadap indek pencapaian standar pelayanan minimal pada satuan pendidikan jenjang SD melalui proses pengelolaan organisasi sekolah. Berdasarkan uraian yang telah disampaikan tersebut, maka penelitian ini bertujuan untuk menghasilkan model evaluasi implementasi kebijakan SPM jenjang SD.

\section{Metode Penelitian}

Desain penelitian yang dirancang dalam penelitian ini merupakan desain penelitian expost facto atau desain non experimantal. Sebagaimana pendapat Isaac \& Michael (1981), penelitian expost facto mencoba menentukan suatu sebab dari sesuatu yang sudah terjadi, oleh karena itu desain penelitian yang demikian tidak ada perlakuan/treatment yang dilakukan peneliti.

Variabel dalam penelitian dijabarkan berdasar tiga komponen yakni komponen Input, Proces dan output yang masing-masing komponen terdiri dari variable laten dan masing-masing variabel laten terdiri dari beberapa variabel manifest. Sehingga dalam penelitian ini terdapat 5 variabel laten dan 33 variabel manifest. Lima variabel laten terdiri dari variabel eksogen dan variabel endogen. Variabel eksogen meliputi (1) KLS; (2) PKS; (3) KSK. Variabel endogen meliputi: (1) PPOS, dan (2) IP-SPM-SD. 
Unit analisis penelitian ini adalah satuan pendidikan jenjang SD, sedangkan populasinya seluruh SD di Kabupaten Pesawaran yakni sebanyak 307 SD yang tersebar pada 11 Kecamatan. Pengambilan sampel dalam penelitian ini dilakukan dengan teknik purposif sampling yakni sebanyak 24 SD pada 4 kecamatan. Responden penelitiannya para guru dan kepala sekolah, sebagai target group SPM dan sekaligus sebagai implementor kebijakan SPM. Untuk setiap sekolah sampel akan diambil satu orang kepala sekolah, dan 2 orang guru yang terdiri dari 1 orang guru senior dan 1 orang lagi guru junior. Teknik pengumpulan data utama menggunakan quesioner, sedangkan wawancara, dan data dokumen akan digunakan sebagai teknik pelengkap.

Kriteria pengujian model dalam penelitian ini digunakan pendekatan SEM dengan program LISREL. LISREL terdiri dari dua kelompok persamaan/model yakni; model struktural (structural mode) dan model pengukuran (measurement mode). Evaluasi kesesuaian model (model fit). Digunakan kriteria overal fit yakni menguji; (a) Chi Square dan Probabilitas, dan (b) Root Mean Square Error of Approximation (RMSEA).

Prosedur yang dilakukan untuk mengembangkan model dalam penelitian ini mengikuti langkah-langkah pemikiran dalam pemodelan SEM. Muhadjir (2007, pp. 358359) menguraikan; SEM menggunakan pemodelan struktural linier dan penstrukturannya menggunakan persamaan dalam matematika. Pemodelan struktural ini dikembangkan dari tuntutan ilmu mutakhir bahwa kebenaran teoritik dituntut terstruktur (structured), dan kebenaran empirik elesperimental dituntut struktural pula. Dengan SEM dimaksudkan agar dapat membangun dan mengembangkan kebenaran konstruk (constructed truth).

Salah satu pemodelan struktural adalah LISREL. LISREL merupakan model matematik formal yang substantive content dalam setiap aplikasinya. Bentuk umum model LISREL terdiri atas seperangkat persamaan linier struktural. Variabel-variabelnya dalam sistem persamaan dengan mengangkat observed variables dan latent variables. Konstruk modelnya berasumsi bahwa ada struktur kausal diantara sejumlah latent variable, dan observed variables dijadikan indikator atau simpton dari latent variable tertentu. Dengan mengacu pada langkah-langkah pembuatan pemodelan menurut Ferdinand (2000, p. 22), Stoelting (Narimawati \& Sarwono, 2007, p. 39), dan Ghozali \& Fuad (2005, p. 9), maka langkah pengembangan model dalam penelitian ini sebagaimana terurai berikut.

Pertama, pengembangan teori/konseptualisasi model. Teori yang digunakan untuk mengembangkan model dalam penelitian ini menggunakan teori berfikir sistem yang komponennya terdiri dari: policy input, policy cycle, dan policy output yang oleh peneliti disebut sebagai model ICO (Input, Cycle, dan Output). Atau disebut juga dengan model IPO (Input, Proses, dan Output). Kedua, menjabarkan Teori ke dalam Komponen, Variabel dan Indikator. Pada langkah ke dua ini peneliti membuat kisi-kisi instrumen sebagai dasar untuk pembuatan draf instrumen penelitian.

Ketiga, menyusun instrumen dan validasi. Langkah awal dalam kegiatan ini adalah membuat draf instrumen yang kemudian divalidasikan dengan melakukan Focus Group Discucion (FGD) bersama para praktisi pendidikan yakni Kepala Unit Pelaksana Teknis Pendidikan (KUPTP), kepala sekolah, komite sekolah, dan para guru di wilayah dinas pendidikan Kabupaten Pesawaran. Partisipan FGD sebanyak 30 orang dan hasil FGD menunjukkan bahwa sebanyak $>50 \%$ partisipan FGD menyatakan setuju dan sangat setuju dengan draf instrumen yang dirancang. Keempat, pengembangan diagram alur dan desain model. Pada langkah ini dikembangkan desain model dengan pola berfikir sistem.

Kelima, konversi Diagram Alur ke dalam Persamaan Struktural. Atas dasar disain model yang telah dirancang, bahwa variabel PPOS memiliki fungsi ganda, dimana selain berperan sebagai variabel eksogen terhadap IP-SPM juga berperan sebagai variabel endogen terhadap KLS, PKS, dan KSK. Jadi secara struktural ada tiga model yang 
dijabarkan dalam penelitian ini. Spesifikasi model struktural berturut-turut adalah; (a) model struktural dukungan PPOS terhadap IP-SPM, (b) Model struktural dukungan KLS, PKS, dan KSK terhadap PPOS, (c) Model struktural dukungan KLS, PKS, dan KSK terhadap IP-SPM.

Keenam, pemilihan teknik estimasi. Tahap ini merupakan pemilihan terhadap nilai parameter awal yang bebas dipilih untuk menentukan matrik kovarian populasi yang diistimasi dari model tersebut. Terdapat beberapa metode estimasi yang dapat digunakan dalam SEM, diantaranya menurut Joreskog \& Sarbon (1996, p. 17), Narimawati \& Sarwono (2007, p. 44), Muhadjir (2007, pp. 359-360). Mengingat banyaknya metode estimasi yang dapat digunakan dalam SEM, dengan mengutip pendapat Hair, Tatham, Anderson, \& Black (1998, p. 605) bahwa dengan metode estimasi Maximum Likelihood (ML) adalah merupakan metode yang paling umum digunakan dalam SEM, dinyatakan bahwa ukuran sampel 50 sudah cukup layak. Atas dasar pendapat Hair maka peneliti memilih metode estimasi Maximum Likelibood (ML).

Ketujuh, Uji Coba Produk. Produk yang dihasilkan dalam penelitian ini adalah: "Model Evaluasi Kebijakan Standar Pelayanan Minimal Satuan Pendidikan Jenjang SD”. Agar mendapatkan model yang tepat, maka harus dilakukan pengujian kecocokan antara model desain secara teoritis yang diajukan dengan data empiris. Oleh karena itu uji coba produk dilakukan dengan menguji kecocokan model teoritik dengan fakta empirik di lapangan. Pengujian kecocokan model dikenakan pada 24 SD yang tersebar pada 4 Kecamatan di wilayah Kabupaten Pesawaran dengan responden sebanyak 72 orang yang terdiri dari 24 orang kepala sekolah, 24 orang guru senior dan 24 orang guru yunior.

Kedelapan, Evaluasi model. Evaluasi dilakukan dengan menggunakan kriteria keselarasan (goodness of fit). Uji keselarasan model akan dilakukan dalam tiga tahapan yakni; (1) uji kesesuaian model pengukuran, (2) uji kesesuaian model struktural, dan (3) uji mo- del secara keseluruhan. Kriteria keselarasan yang digunakan dalam penelitian ini adalah; (1) Chi-Square $\left(X^{2}\right)$, dan Probabilitas (p); (2). Root Mean Square Error of Approximation (RMSEA).

Secara ringkas langkah pengembangan model tertuang dalam Gambar 2.

1. Pengembangan teori/Konseptualisasi Model

$\perp 5$

3. Menjabarkan Teori ke dalam Komponen, Variabel dan Indikator.

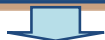

2. Menyusun instrumen dan validasi $\lcm{2}$

4. Pengembangan Diagram alur dan desain model

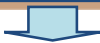

6. Konversi Diagram Alur ke dalam Persamaan Struktural

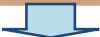

5. Pemilihan teknik estimasi

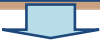

7. Uji Coba Produk

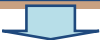

8. Evaluasi model

Gambar 2. Langkah Pengembangan Model

\section{Hasil Penelitian}

Uji Model Keseluruhan (Overal/Fit)

Hasil pengujian Goodness of Fit Index nampak bahwa, Chi-Square $\left(X^{2}\right)$ dan Probability ( $p$ ) sebesar 517.32 dengan p $0.06457>$ p 0.05. Kemudian Root Mean Square Error of Approximation (RMSEA) sebesar 0,038 $\leq$ 0.05. Hasil ini menunjukkan bahwa model terpenuhi yang berarti bahwa model teoritik yang dihipotesiskan sesuai dengan fakta empiris di lapangan. Dengan demikian hipotesis kesatu diterima, artinya model yang tepat untuk mengevaluasi IP-SPM-SD adalah bila di dukung oleh; KLS). PKS, KSK, dan PPOS. 
Uji Model Pengukuran

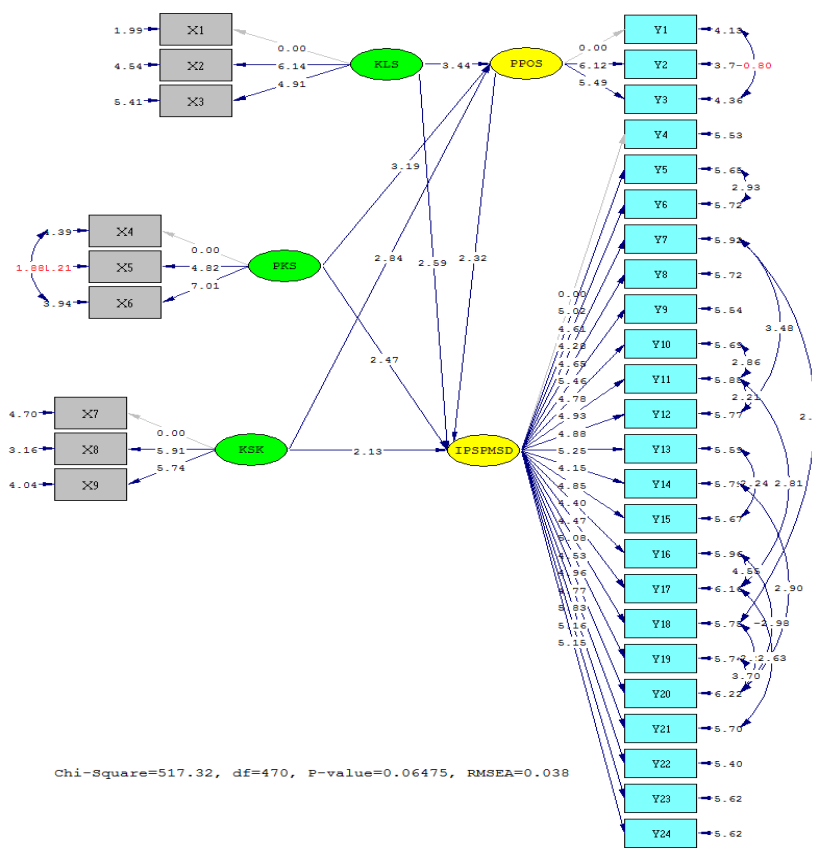

Gambar 3. Pengujian Model Pengukuran

Hasil uji pengukuran menunjukkan bahwa semua variabel terlihat memiliki t-hitung $>2$ sehingga dinyatakan signifikan. Hal ini berarti IP-SPM SD berhasil direflek-si variabel KLS, PKS, KSK, dan PPOS. Maknanya adalah bahwa variabel KLS, PKS, KSK, dan PPOS merupakan variabel yang bisa diangkat sebagai dimensi untuk mengukur IP-SPM-SD. Hasil uji pengukuran dapat dilihat dalam Tabel 1.

Tabel 1. Ringkasan Hasil Pengukuran IP-SPM-SD

\begin{tabular}{lllll}
\hline No & Variabel & $\lambda$ Standar & t-hitung & Keterangan* \\
\hline 1 & KLS & 0.3454 & 2.5852 & Signifikan \\
2 & PKS & 0.3103 & 2.4738 & Signifikan \\
3 & KSK & 0.2480 & 2.1298 & Signifikan \\
4 & PPOS & 0.3929 & 2.3236 & Signifikan \\
\hline
\end{tabular}

Uji Model Struktural

Berdasarkan nilai t-hitung dalam fungsi struktural bisa dianalisis bahwa:

Pertama, PPOS signifikan terhadap IPSPM-SD yang ditunjukkan dengan nilai thitung sebesar $2.32>2$. Hasil ini memberi arti bahwa hipotesis kedua dapat diterima. Maknanya adalah bahwa PPOS merupakan pendukung langsung yang signifikan terhadap IP-SPM-SD. Kedua, untuk menguji hipotesis ketiga, keempat, dan kelima, ada dua fungsi dalam model yang diuji: (1) menjelaskan dukungan KLS, PKS, dan KSK terhadap PPOS, (2) menjelaskan dukungan KLS, PKS, KSK, dan PPOS terhadap IPSPM SD. Untuk menganalisisnya maka berdasarkan hasil pengujian struktural model dapat dilihat dalam Tabel 2 dan Gambar 4.

Tabel 2. Hasil Pengujian Struktural

\begin{tabular}{|c|c|c|c|c|}
\hline Fungsi & Endogen & Eksogen & Koefisien & ${ }^{\mathrm{t}-}{ }^{-}$ \\
\hline \multirow[t]{3}{*}{1} & PPOS & KLS & 0.4644 & 3.4448 \\
\hline & & PKS & 0.4254 & 3.1871 \\
\hline & & KSK & 0.3721 & 2.8414 \\
\hline \multirow[t]{4}{*}{2} & IP-SPM- & KLS & 0.3454 & 2.5852 \\
\hline & SD & PKS & 0.3103 & 2.4732 \\
\hline & & KSK & 0.2480 & 2.1298 \\
\hline & & PPOS & 0.3929 & 2.3236 \\
\hline
\end{tabular}

* (Ferdinand, 2000), t-hitung $>2$ signifikan

Persamaan fungsi pertama dapat ditulis: PPOS $=0.4644 \mathrm{KLS}^{\text {sig }}+0.4254 \mathrm{PKS}^{\text {sig }}$ $+0.3721 \mathrm{KSK}^{\text {sig. }}$. Dalam persamaan ini variabel KLS, PKS, KSK semua signifikan yang berarti bahwa semua variabel tersebut memiliki kontribusi mendukung PPOS. Berdasarkan uraian pada persamaan fungsi pertama tersebut, mengindikasikan bahwa hipotesis ketiga diterima. Maknanya adalah Proses pengelolaan organisasi sekolah didukung langsung secara signifikan oleh kondisi lingkungan sekolah, pelaksana kebijakan sekolah, dan kelompok sasaran kebijakan sekolah.

Persamaan fungsi kedua dapat ditulis, IP-SPM-SD $=0.3454 \mathrm{KLS}^{\text {sig }}+0.3103 \mathrm{PKS}^{\text {sig }}$ $+0.2480 \mathrm{KSK}^{\text {sig }}+0.3929 \mathrm{PPOS}^{\text {sig. }}$. Dalam persamaan semua variabel signifikan yang berarti bahwa variabel KLS, PKS, KSK, dan PPOS memiliki kontribusi dalam menjelaskan IP-SPM-SD. Berdasarkan pada uraian persamaan fungsi kedua ini mengindikasikan bahwa hipotesis keempat diterima. Maknanya adalah bahwa, IP-SPM-SD didukung langsung secara signifikan oleh KLS, PKS, KSK, dan PPOS.

Selain menunjukkan kebermaknaan pengaruh variabel eksogen terhadap variabel endogen, hasil pengujian struktural juga 
menunjukkan pengaruh KLS, PKS, dan KSK, terhadap IP-SPM-SD secara tidak langsung melalui PPOS. Dengan demikian hal ini mengindikasikan bahwa hipotesis kelima diterima. Makna hasil pengujian ini adalah bahwa, KLS, PKS, dan KSK merupakan pendukung tidak langsung secara signifikan terhadap IP-SPM-SD. Melalui PPOS.

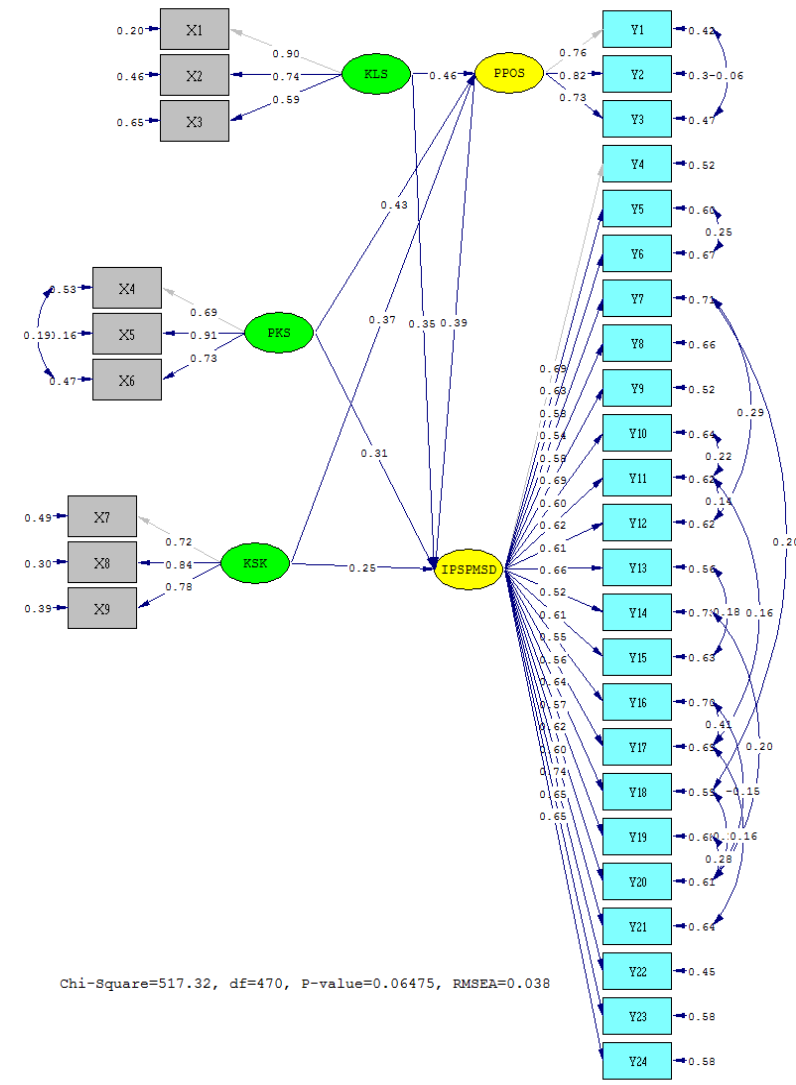

Gambar 4. Pengujian Model Struktural

Pembahasan

Temuan penelitian ini mendukung teori model implementasi kebijakan yang dikemukakan oleh beberapa ahli: Grindle (1980) yang menyatakan bahwa setiap implementasi kebijakan perlu mempertimbangkan konteks atau kondisi lingkungan dimana tindakan (action) dilakukan. Mengacu pada pendapat Grindle berarti bahwa ling-kungan adalah merupakan faktor penentu kinerja implementasi kebijakan. Mazmanian \& Sabatier (1986) mengemukakan bahwa suatu implementasi kebijakan akan efektif apabila pelaksananya mematuhi apa yang telah digariskan oleh peraturan (petunjuk teknis, petunjuk pelaksanaan). Selanjutnya diutarakan bahwa kelompok sasaran juga harus mematuhi program, tanpa kepatuhan mereka tujuan kebijakan tidak akan tercapai. Mengacu pada pendapat Mazmanian dan Sabatier berarti bahwa kelompok sasaran dan pelaksana kebijakan juga merupakan faktor penentu kinerja implementasi kebijakan.

Van Meter \& Van Horn (1973) mengemukakan bahwa kinerja implementasi kebijakan akan ditentukan oleh faktor; standar dan sasaran, sumberdaya, komunikasi antarorganisasi, karakteristik organisasi pelaksana, dan kondisi sosial, ekonomi dan politik. Kelima faktor ini akan membentuk sikap pelaksana terhadap kebijakan yang akan diimplementasikan dan akhirnya mempengaruhi terhadap kinerja implementasi sebuah kebijakan.

Cheema \& Rondinelli (1983) mengutarakan adanya 4 faktor yang dipandang dapat mempengaruhi implementasi kebijakan yang disarankan sebagai variabel bebas yakni; kondisi lingkungan, hubungan antarorganisasi, sumber daya, dan karakter agen pelaksana. Membuktikan pendapat Cheema dan Rondineliy, hasil penelitian Khozin (2010, pp. 50-54) bahwa kendala utama pelaksanaan SPM di lapangan adalah pada faktor pendanaan, koordinasi antarunsur dalam organisasi pelaksana dan rendahnya komitmen SDM.

Implikasi diterimanya model teoritis ini diharapkan menjadi follow up bagi pengelola program untuk melakukan pembinaan terhadap kinerja sekolah dalam mengimplementasikan kebijakan SPM SD. Implikasi ini di dukung hasil penelitian Rahayu (2015, pp. 62-79) bahwa diperlukan dukungan bagi sekolah-sekolah untuk dapat mengoptimalkan pelaksanaan aspek-aspek pegelolaan sekolah agar lebih sesuai dengan standar-standar pengelolaan pendidikan yang berlaku.

\section{Simpulan}

Berdasarkan hasil penelitian dan pembahasan yang disajikan, penelitian ini memberikan simpulan bahwa KLS, PKS, KSK, dan PPOS merupakan faktor-faktor dinamis yang membentuk model yang tepat untuk mengevaluasi IP-SPM-SD. 


\section{Daftar Pustaka}

Adawiah, R. (2011). Standar pelayanan pendidikan di Kabupaten Balangan. Banjarmasin. Retrieved from http:/ / eprints.ulm.ac.id/72/

Cheema, G. S., \& Rondinelli, D. A. (1983). Policy implementation in developing countris, UNCRD. Baverly Hill, CA: Sage Publication.

Dunn, W. N. (1998). Pengantar analisis kebijakan publik (Terjemahan Samodra Wibawa, dkk) (2nd ed.). Yogyakarta: UGM Press.

Edwards III, G. C. (1980). Implementing public policy. Washington, D.C: Conggressional Quarterly.

Ferdinand, A. T. (2000). Structural equation modeling dalam penelitian manajemen. Semarang: Badan Penerbit Universitas Diponegoro.

Ghozali, I., \& Fuad. (2005). Structural equation modeling. Teori, konsep dan aplikeasi dengan program Lisrel 8.80. Semarang: Badan Penerbit Universitas Diponegoro.

Grindle, M. S. (1980). Polities and policy Implementation in the third world. New Jersey: Princeton University Press.

Hair, J. F., Tatham, R. L., Anderson, R. E., \& Black, W. (1998). Multivariate data analysis (5th ed.). London: Prentice Hall International.

Hermawan, K. D. (2011). Evaluasi Program SMP Standar Nasional Berdasarkan Standar Nasional Pendidikan. Jurnal Pendidikan Dan Kebudayaan, 17(6), 619. https://doi.org/10.24832/jpnk.v17i6. 54

Isaac, S., \& Michael, W. B. (1981). Handbook in research and evaluation for education and behavioral Sciences (2nd ed.). San Diego, California 92107: EdITS Publishers.

Jones, C. O. (1994). An introduction to study of public policy. Montery-California: Brooks/Cole Publishing Company.
Joreskog, K. G., \& Sarbon, D. (1996). Lisrel 8: User's reference guide. Chicago:

Scientific Sofware International.

Khozin, M. (2010). Evaluasi implementasi kebijakan standar pelayanan minimal bidang kesehatan di Kabupaten Gunungkidul. Jurnal Studi Pemerintahan, 1(1). Retrieved from http://journal.umy.ac.id/index.php/js $\mathrm{p} /$ article/view/177

Koster, W. (2000). Restrukturisasi penyelenggaraan pendidikan: studi kapasitas sekolah dalam rangka desentralisasi pendidikan. Jurnal Pendidikan Dan Kebudayaan, 6(26).

Mazmanian, D., \& Sabatier, P. (1986). Effective olicy implementation. Lexington: D.C, Heath.

Menteri Pendidikan dan Kebudayaan Republik Indonesia. (2013). Permendikbud No 23 Tahun 2013 tentang Standar Pelayanan Minimal (SPM) Pendidikan Dasar di Kabupaten/Kota.

Muhadjir, N. (2007). Metodologi keilmuan. paradigma kualitatif, kuantitatif, dan mixed (5th ed.). Yogyakarta: Rake Sarasin.

Mustopadidjaja, A. R. (2002). Manajemen proses kebijakan publik. Formulasi, implementasi, dan evaluasi kinerja. Jakarta: Lembaga Administrasi Negara-RI.

Narimawati, U., \& Sarwono, J. (2007). Structural equation model (SEM), dalam riset ekonomi menggunakan LISREL. Yogyakarta: Gava Media.

Rahayu, M. (2015). Pelaksanaan standar pengelolaan pendidikan di sekolah dasar kecamatan Ngemplak. Jurnal Penelitian Ilmu Pendidikan, 8(1), 62-79.

Rossi, P. H., \& Freeman, H. E. (1982). Evaluation a systematic approach. London: Sage Publication.

Sabdaningtyas, L. (2010). Model evaluasi implementasi kebijakan desentralisasi pendidikan pada satuan sekolah di Propinsi Lampung. Disertasi Tidak 
dipublikasikan.

Satori, D. (1999). Analisis kebijakan dalam konteks desentralisasi dan otonomi pendidikan. Jakarta: Biro Perencanaan Sekretariat Jendral Depdikbud.

Solongi, B. (2015, April 11). UN atau Pemenuhan SPM Pendidikan.

Tribunnews. Retrieved from http://makassar.tribunnews.com/201 5/04/06/un-atau-pemenuhan-spmpendidikan

Sudjana, D. (2006). Evaluasi program pendidikan luar sekolah. Bandung: PT Remaja Rosdakarya.
Van Meter, D. S., \& Van Horn, C. E. (1973). The policy implementation process a conceptual framework in administration and society. Beverly Hills: Sage Publication.

Wibawa, S., Prabuningrat, Y., \& Pramusinto, A. (1994). Evaluasi kebijakan publik. Jakarta: Raja Grafindo Persada.

Worthen, B. R., \& Sanders, J. R. (1973). Educational evaluation: theory and practice. Belmont, Calofornia: Wadsworth Publishing Company, Inc. 